\title{
Kobieta i kobiecość w ujęciu Tomasza z Akwinu a neotomistyczna etyka feministyczna. Analiza krytyczna
}

\author{
Tatiana Barkovskiy \\ (Uniwersytet Warszawski, Wydział Filozofii i Wydział Neofilologii)
}

\section{Wprowadzenie}

Można wyróżnić wielu filozofujących teologów (i trochę mniej filozofek-teolożek), których doktryny stanowią rdzeń chrześcijańskiej - a w szczególności katolickiej - etyki. Jako najbardziej wpływową postać należy natomiast wskazać Tomasza $\mathrm{z}$ Akwinu, którego spuścizna przybrała formę jednego $\mathrm{z}$ wiodących obecnie nurtów feministycznej etyki chrześcijańskiej. Skonstruowana przez niego antropologia wywarła głęboki wpływ na myślenie o kobiecie. Do niedawna jego wypowiedzi dotyczące kobiecości przyjmowano jednak bardzo wybiórczo i pozostawiano na ogół te elementy, które narzucały kobietom bardzo ograniczoną rolę kulturową ${ }^{1}$ Z $\mathrm{Z}$ tego powodu dominujący w powszechnej świadomości obraz Akwinaty nacechowany jest przekonaniem o nierozerwalnej z jego postacią mizoginii.

Mimo to istnieją feministyczne recepcje tomizmu. Wobec tego nasuwa się pytanie, czy pogodzenie tomizmu z feminizmem jest rzeczywiście możliwe. Niniejszy artykuł stanowi próbę pogłębionej analizy koncepcji kobiecości w ujęciu Tomasza z Akwinu poprzez wyjście ponad klasycznie badaną q. 92 z części I Summa theologiae i objęcie jego wypowiedzi na temat kobiet i kobiecości zawar-

E. Adamiak, Kobieta w Kościołach i wspólnotach chrześcijańskich. Próba syntezy teologicznej, „Poznańskie Studia Teologiczne” 2001, T. 11, s. 100. 
tych w innych dziełach, a także skontrastowanie ich z myślą filozofa, na którego stwierdzeniach zazwyczaj opierał swoje rozważania w badanym zakresie - Arystotelesa. Przedstawione zostaną m.in. główne zarzuty, które można postawić pod adresem Akwinaty z punktu widzenia myśli feministycznej, oraz sposoby, w jakie do tej pory próbowano pogodzić jego poglądy z feminizmem. Celem tych analiz jest przygotowanie podstaw do zmierzenia się nie tylko ze wspomnianą wyżej wątpliwością co do spójności tych dwóch koncepcji, lecz także z pytaniem, czy tomizm jest dla etyki feministycznej adekwatnym gruntem.

\section{Kobieta według Arystotelesa}

Tomasz większość deprecjonujących kobiety poglądów czerpie z dorobku Arystotelesa, choć zdarza się, że przywołując je, przedstawia własną interpretację. Warto więc najpierw przytoczyć najważniejsze w tym kontekście opinie, które o kobiecej części ludzkości formułował Filozof na przestrzeni swoich dzieł i które zostały następnie podjęte przez Akwinatę. Jak wspomniano, posłużą one jedynie do skontrastowania z nimi poglądów Akwinaty. Nie zostaną więc poddane głębszej refleksji, a jedynie przytoczone w swojej najbardziej esencjonalnej formie.

W kontekście etycznym Arystoteles zakłada immanentną kobiecie niższą wartość w stosunku do mężczyzny. W Etyce Nikomachejskiej pisze, że pozostaje ona w stosunku niższości i poddaństwa do mężczyzny na tej samej zasadzie, co sługa do swojego pana i syn do ojca, a w takim rodzaju relacji jedna strona nie powinna ani otrzymywać, ani żądać od drugiej tego, co sama jej daje, i wszelkie uczucia w niej zaistniałe powinny być proporcjonalne do wartości każdej ze stron $^{2}$. Choć Arystoteles nie pisze o tym explicite, to nasuwa się następujące pytanie: czy kobieta - jako „niższa” - powinna bardziej kochać i szanować swego męża niż on ją?

Odpowiedni stosunek między mężem a żoną przypomina ustrój arystokratyczny, ponieważ mąż, jako ten o większej wartości, ma nad żoną władzę. W sytuacji, gdy w danym domostwie rządzi kobieta (która np. jako dziedziczka ma większą moc finansową), relacja ta jest oligarchiczna, ponieważ władza w domu nie jest oparta na dzielności etycznej i ogólnej szlachetności, lecz na bogactwie

2 Arystoteles, Etyka Nikomachejska, VIII.7.1158b, tłum. D. Gromska, PWN, Warszawa 1982, s. 299. 
i wynikających z niego wpływach ${ }^{3}$. Miłość w małżeństwie, o ile utrzymana jest w prawidłowym ustroju arystokratycznym, wynika właśnie z areté i tego, kto jest więcej wart - żona i mąż otrzymują należycie to, co jest dla nich „odpowiednie” i dobre ${ }^{4}$. Arystoteles rozwija problem władzy w Polityce, gdzie pisze, że kobieta jest $z$ natury mniej uzdolniona do rządzenia niż mężczyzna ${ }^{5}$. Chociaż pozostawia miejsce dla wyjątków, to mimo to udostępnienie jej zbyt dużej swobody uważa za szkodliwe i prowadzące do chaosu ${ }^{6}$. Porównując kobietę do niewolnika, twierdzi, że w przeciwieństwie do niego, który wcale nie posiada zdolności do rozważania, kobieta tę zdolność posiada, chociaż „niezbyt kompetentną”7. Zarówno mężczyzna, jak i kobieta posiadają cnotę etyczną, jednak jej realizacja nie jest u nich taka sama ${ }^{8}$. Myśl ta stanowi uzasadnienie wcześniej nakreślonych stosunków władzy. Wszystko to sprawia, że kobieta jest niezdolna do samodzielnego wychowywania swoich dzieci. Zajmuje bardzo wątpliwe miejsce w społecznej hierarchii Stagiryty ${ }^{9}$.

Z kolei w kontekście anatomiczno-psychologicznym, poruszonym np. w Zoologii, według Arystotelesa kobieta

[...] jest bardziej współczująca niż mężczyzna i więcej skłonna do łez; jest więcej zazdrosna i więcej skłonna do użalania się na los, do miotania zniewag i do bicia; łatwiej się zniechęca i popada w rozpacz; jest więcej bezczelna i więcej kłamliwa; daje się łatwiej oszukać i mniej prędko zapomina; ona wreszcie mniej odczuwa potrzebę spania, lecz także jest mniej czynna i na ogół bardziej powolna w działaniu niż mężczyzna; poprzestaje na mniejszej ilości pokarmu ${ }^{10}$.

Tamże, VIII.10.1160b-1161a, s. 308. Należy jednak dodać, że Arystoteles krytykuje również tych mężczyzn, którzy całą władzę w domu zagarniają dla siebie - taki stan także nazywa oligarchią. „Arystokratyczność” władzy męża realizuje się wtedy, gdy przekazuje ją kobiecie w „dziedzinach, które jej przystoją".

4 Tamże, VIII.11.1161a, s. 309.

5 Arystoteles, Polityka, I.5.1259b, tłum. L. Piotrowicz, PWN, Warszawa 1964, s. 31.

6 Tamże, II.6.1269b-1270a, s. 73-75.

7 Tamże, I.5.1260a, s. 34.

8 Tamże, oraz: III.2.1277b, s. 105.

9 Por. M. Uliński, Płeć jako determinanta roli i pozycji społecznej według nauki Arystotelesa, „Archiwum Historii Filozofii i Myśli Społecznej" 1996, nr 41, s. 3-20.

10 Arystoteles, Zoologia, IX.1.608b, tłum. P. Siwek, PWN, Warszawa 1982, s. 364. 
Jej rola w akcie miłosnym jest bierna, a nie czynna ${ }^{11}$. W końcu należy przytoczyć myśl, którą w Summa theologiae cytuje Akwinata: kobieta nie produkuje nasienia, lecz „zdeformowaną” krew menstruacyjną, wobec czego jest ä $\rho \rho \varepsilon v$ $\pi \varepsilon \pi \eta \rho \omega \mu \varepsilon \dot{v} o v^{12}$, „niedorozwiniętym” czy „zdeformowanym”13 mężczyzną. Podejmowano różne próby egzegezy tego stanowiska, na przykład poprzez zwrócenie się do koncepcji embriologicznej Arystotelesa ${ }^{14}$.

Oczywiście nie należy zapominać o tym, że Arystoteles, jak każdy inny myśliciel, podlega uwarunkowaniom historyczno-kulturowym swojej epoki. Można wymienić wiele elementów jego filozofii, których dziś nie przyjmuje się na poważnie: od niektórych postulatów biologicznych, do kwestii etyczno-politycznych, takich jak uznawanie niewolnictwa za naturalne, akceptacja niedemokratycznych rządów czy właśnie przyjmowanie za fakt niższości kobiet w stosunku do mężczyzn. Co istotne, nawet na gruncie jego myśli, po odrzuceniu pewnych jej elementów, jest możliwe utworzenie spójnego dyskursu o zabarwieniu feministycznym, co pokazuje przypadek Marthy Nussbaum ${ }^{15}$.

Tak jak wspomniano, poglądy Arystotelesa przytoczono tu nie w celu ich krytyki, lecz jako istotne tło dla rozważań Tomasza, którego myśl może stanowić rdzeń współczesnej chrześcijańskiej etyki feministycznej. Skontrastowanie poglądów tych dwóch myślicieli jest kluczowe dla wykazania, że Akwinata, znany jako kontynuator myśli Arystotelesa i, według niektórych, w pewnym sensie „przeciwnik” kobiet, nie przejmuje od Stagiryty wszystkich założeń w obszarze badanego zagadnienia, lecz często dodaje do jego spostrzeżeń nową perspekty-

11 Tenże, Etyka Nikomachejska, VII.5.1148b-1149a, dz. cyt., s. 253. Jest to odniesienie do czysto fizjologicznego aktu prokreacji, a nie płciowego, związanego z przyjemnością. Arystoteles nie neguje czerpania przez kobiety przyjemności ze stosunku płciowego - zastanawia się za to, czy kobiecy orgazm (rozumiany jako „emisja kobiecego nasienia”) jest potrzebny do poczęcia. Odpowiada sprzecznie: w O rodzeniu się zwierząt (II.3.739b, tłum. P Siwek, PWN, Warszawa 1979, s. 85) przecząco, w Zoologii (X.6.638a, dz. cyt., s. 460) - twierdząco.

12 Arystoteles, De generatione animalium, II.3.737a, w: tegoż, Opera, ed. I. Bekkeri, t. V, Oxford University Press, Oxford 1837, s. 249.

13 W przekładzie P. Siwka: „samica jest jakby samcem pozbawionym pewnych części” (Arystoteles, O rodzeniu się zwierząt, II.3.737a, dz. cyt., s. 78). Wyrażenie „zdeformowany mężczyzna” to naleciałość z tłumaczenia A.L. Pecka (Generation of Animals, Harvard University Press, Harvard 1942): "the female is as it were a deformed male”.

14 Por. M. Trepczyński, T. Ishikawa, Czy kobieta to niewydarzony mężczyzna? Metafizyka płci z perspektywy Tomasza z Akwinu i dzisiejszej biologii, „Przegląd Filozoficzny - Nowa Seria” 2017, nr 2(102) i cytowana literatura.

15 Por. M. Nussbaum, Social Justice and Universalism: In Defense of an Aristotelian Account of Human Functioning, „Modern Philology” 1993, 90 Suppl., s. 46-73. 
wę. Wymienione poniżej wypowiedzi Tomasza i związane z nimi analizy zostały przedstawione w porządku najważniejszych zarzutów, które można mu wytoczyć na gruncie paradygmatu feministycznej wrażliwości.

\section{Główne zarzuty wobec Tomasza z Akwinu}

\subsection{Zależność kobiety od mężczyzny}

Zdaniem Tomasza kobiety mają słabe usposobienia i często podlegają nadmiernemu wpływowi pasji, wobec czego ich zdolności poznawcze nie są w pełni wiarygodne. W Summa theologiae pisze on:

Jeśli chodzi o kobiety, ponieważ ich cielesna konstytucja jest słaba, zazwyczaj słabo trzymają się tego, czego postanowiły się trzymać, chociaż zdarzają się wyjątki [...]. A ponieważ to, czego jest mało lub co jest słabe, uważa się prawie za nic, dlatego Filozof wyraża się o kobietach, jako nie mających wystarczająco mocnego sądu rozumu, chociaż o niektórych kobietach tego powiedzieć nie można. Dlatego uważa on, że nie mówimy o kobietach, że są powściągliwe, ponieważ kierują się nie stałością rozumu, lecz łatwo dają się powodować uczuciom $^{16}$.

Pozostając w duchu arystotelejskim Tomasz pisze, że to „naturalne utrudnienie” występujące u większości kobiet uniemożliwia im pełne korzystanie ze zdolności racjonalnych. Ponadto sama racjonalność i tak jest u nich w pewnym sensie upośledzona; w związku z tym w sądzie nie można polegać na ich zeznaniach ${ }^{17}$. Celem kobiety jest to, czego mężczyzna nie może dokonać samodzielnie - prokreacja:

Konieczne było, żeby stała się kobieta - jak mówi Pismo św.: jako odpowiednia pomoc dla mężczyzny; nie jako pomoc do jakiejś innej pracy - jak to nie-

16 Tomasz z Akwinu, Summa theologiae (dalej jako: ST), II-II, q. 156, a. 1 ad 1, cyt. z: Tomasz z Akwinu, Suma teologiczna, tłum. P. Bełch, t. 22, Veritas, Londyn 1963, s. 102.

17 ST, II-II, q. 70, a. 3., t. 18, s. 108-109. „Czyjeś świadectwo nie ma siły przekonywującej niekiedy zaś bez jego winy, a to albo z powodu niedomagania rozumu, np. u dzieci, chorych umysłowo i kobiet [...]". 
którzy mówili - gdyż w każdej innej pracy mężczyzna może wydatniej nieść pomoc mężczyźnie niż kobieta, ale jako pomoc do rodzenia ${ }^{18}$.

W przedstawionej w Summa contra gentiles argumentacji przeciwko cudzołóstwu Akwinata uznaje, że małżeństwo jest konieczne dla dobra potomstwa. Jego argument ma podłoże naturalistyczne. Kontrastuje tu człowieka ze zwierzętami i stwierdza, że w jego przypadku do wychowania dziecka jest potrzebna zarówno matka, jak i ojciec - matka karmi ciało dziecka, a ojciec jego duszę, jako obdarzony „doskonalszym rozumem do pouczania”:

Należy także zauważyć, że potomstwu człowieka potrzeba nie tylko odżywiania co do ciała, jak innym zwierzętom, lecz także nauczania w zakresie duszy. Inne zwierzęta mają bowiem z natury pewną roztropność, która pozwala im troszczyć się o siebie, człowiek zaś żyje rozumem, który doświadczeniem zbieranym przez długi czas musi dochodzić do roztropności, muszą więc dzieci być pouczane przez rodziców, mających już doświadczenie. Pouczenia tego nie mogą przyjąć dzieci zaraz po urodzeniu, lecz po dłuższym czasie, a zwłaszcza gdy dojdą do używania rozumu. Potrzeba też dłuższego czasu dla tej nauki. A wtedy także z powodu naporu namiętności, które psują roztropną ocenę, potrzeba im nie tylko nauki, ale i skarcenia. Tu zaś nie wystarcza sama niewiasta, lecz potrzeba raczej mężczyzny, który ma doskonalszy rozum do pouczania i większą siłę do karcenia. A zatem nie wystarcza dla człowieka krótkie opiekowanie się potomstwem, jak u ptaków, lecz musi ono trwać przez długi okres życia. Stąd, skoro jest rzeczą potrzebną wśród zwierząt, by samiec nie opuszczał samicy, póki praca ojca jest dla potomstwa konieczna, jest naturalne dla człowieka, by nie na krótki czas, ale trwałym związkiem łączył się z jakąś kobietą. Związek ten nazywamy małżeństwem. Małżeństwo jest więc dla człowieka naturalne, a obcowanie w nierządzie, będące poza małżeństwem, sprzeciwia się dobru człowieka. I dlatego musi być grzechem ${ }^{19}$.

Dalej Tomasz pisze za Arystotelesem, że kobieta nie jest wystarczająco kompetentna, by samodzielnie wychowywać swoje dzieci. Chociaż - w myśl chrześcijańskiej doktryny, że przedstawiciele obu biologicznych płci stworzeni są na

18 ST, I, q. 92, a. 1, t. 7, s. 65 .

19 Tomasz z Akwinu, Summa contra gentiles (dalej jako: SCG), III, q. 122, a. 8, cyt. z: Tomasz z Akwinu, Summa contra Gentiles. Prawda wiary chrześcijańskiej, tłum. Z. Włodek i W. Zega, t. 2, W drodze, Poznań 2007, s. 360-361. 
obraz Boga - posiada rozum, to jednak stopień rozumności jest u niej mniejszy niż u mężczyzny. Z tego względu powinna być wobec niego podległa:

Kobieta bowiem potrzebuje mężczyzny nie tylko, aby mieć potomstwo, jak to jest $\mathrm{u}$ innych zwierząt, lecz także, by nią ktoś rządził, mężczyzna bowiem ma rozum doskonalszy i większą siłę. Mężczyzna zaś dobiera sobie kobietę, bez której nie może mieć potomstwa. Gdy zatem niewiasta przestanie już być płodna i piękna, nikt inny jej nie przyjmie. Gdyby więc ktoś, przyjmując niewiastę w jej młodości, gdy jest płodna i piękna, mógł ją porzucić, gdy postąpi w latach, czyniłby jej krzywdę, co jest przeciwne naturalnej sprawiedliwości ${ }^{20}$.

Dla Tomasza małżeństwo stanowi usankcjonowaną przez Boga unię kobiety i mężczyzny, ciągnącą się aż do ich śmierci. Jako instytucja jest potrzebne, ponieważ bez niego mężczyzna może porzucić kobietę po tym, gdy ta da mu potomstwo. Chociaż z powyższej analizy może wynikać, że dla Tomasza prokreacja jest najważniejszym celem małżeństwa, taki wniosek stanowi znaczne uproszczenie.

Akwinata wyróżnia dwa poziomy perfekcyjności rzeczy - pierwszym jest jej forma, dzięki której dana rzecz jest tym, czym jest (a zatem określa jej istotę), drugi zaś wywodzi się z pierwszego i polega na działaniu, dzięki któremu dana rzecz osiąga swój cel $^{21}$. Celem tego rozróżnienia jest wykazanie, w jaki sposób prawomocnie zawarte, lecz nieskonsumowane małżeństwo Maryi i Józefa było prawdziwym małżeństwem. Forma stanowiąca małżeństwo jest „pewnym niepodzielnym związkiem umysłów i serc, przez który każdy z małżonków jest zobowiązany być wiernym drugiemu w sposób niepodzielny" ${ }^{22}$. Celem małżeństwa jest zaś prokreacja oraz wspólne wychowywanie i karmienie potomstwa. Należy dodatkowo rozróżnić dwa rodzaje celowości: cel właściwy, suum finem, to realizacja formy; prokreacja to cel ostatecznie drugorzędny, wynikający z pierwszej doskonałości małżeństwa - to coś, dzięki czemu małżeństwo w „pewien sposób” (aliqualiter), a zatem w sposób niekonieczny, okazjonalny, osiąga swój szczególny cel. W takim rozumieniu małżeństwo Matki Boskiej i Józefa nie traci na swojej doskonałości ${ }^{23}$.

20 SCG, III, q. 123, a. 3, t. 2, s. 362.

21 A. Oliva, Essence et finalité du mariage selon Thomas d'Aquin: pour un soin pastoral renouvelé, „Revue des Sciences philosophiques et théologiques” 2014, Vol. 98, No. 4, s. 602-603.

22 Tomasz z Akwinu, Scriptum super Sententiis, IV, q. 27, a. 1, ad 2.

23 ST, III, q. 29, a. 2. 
Tomasz wyróżnia dwa obszary, na których realizują się te perfekcyjności. Człowiek jest zwierzęciem - społecznym, lecz zwierzęciem. Głównym celem małżeństwa wynikającym z przynależności człowieka do królestwa zwierząt jest prokreacja, stanowiąca akt przedłużania gatunku; z kolei celem wynikającym z ludzkiego człowieczeństwa jest przyjaźń i niesienie wzajemnej pomocy w małżeństwie ${ }^{24}$. Ostatecznie Tomasz podkreśla dobrą relację między kobietą a mężczyzną jako najwyższy cel każdego związku płciowego między nimi ${ }^{25}$. Dzięki temu niektóre interpretacje tomistycznej doktryny o małżeństwie uznają możliwość dostępu osób rozwiedzionych do komunii lub ponownego małżeństwa ${ }^{26}$.

Małżeństwo ma zatem dwa cele: pierwszym jest prokreacja, a drugim utrzymywanie męża i żony w stanie przyjaźni, który ułatwi spełnienie pierwszego celu. Przyjaźń ta wymaga jednak pewnej formy równości ${ }^{27}$. Ta naturalna równość może zostać podważona przez praktykę małżeństw poligamicznych. W sytuacji, gdy żona ma więcej niż jednego męża, to pochodzenie (i związane z nim dziedziczenie) jej potomstwa nie jest jasne, co przeciwstawia się naturalnej chęci posiadania pewności, że dane potomstwo jest własne. W odwrotnej sytuacji, tj. męża posiadającego wiele żon, ten argument nie ma znaczenia, ponieważ męskie pochodzenie danego potomstwa zawsze będzie jasne. Jednak według Tomasza taka sytuacja jest niesprawiedliwa dla kobiet, które pozostając w związku z mężem posiadającym wiele żon, przy jednoczesnym pozbawieniu tego przywileju, są zredukowane do poziomu niewolnic ${ }^{28}$ - równość małżeńska zostaje zniszczona ${ }^{29}$.

W tym miejscu napotykamy dylemat. $Z$ jednej strony, jak wykazano wcześniej, Akwinata twierdzi, że kobieta powinna być uległa wobec mężczyzny. Z drugiej strony mówi o równości małżeńskiej. Wydaje się, że takie podejście może być spójne, jeśli weźmiemy pod uwagę fakt, że Tomasz wyróżnia kilka rodzajów równości ${ }^{30}$. W Komentarzu do Etyki Nikomachejskiej przytacza pogląd Arystotelesa głoszący, że przyjaźń między nierównymi stronami wciąż związana jest z pewną

\footnotetext{
Tamże.

A. Oliva, Essence et finalité du mariage selon Thomas d'Aquin, dz. cyt., s. 607.

Tamże, s. 650-660.

C. McCluskey, An Unequal Relationship Between Equals: Thomas Aquinas On Marriage, „History of Philosophy Quarterly” 2007, Vol. 24, No. 1, s. 5.

SCG, III, q. 124.

29 Por. P.J. Cornish, Marriage, Slavery, and Natural Rights in the Political Thought of Aquinas, „The Review of Politics" 1998, Vol. 60, No. 3, s. 545-561.

C. McCluskey, An Unequal Relationship Between Equals, dz. cyt., s. 6.
}

30 
formą równości ${ }^{31}$, która realizuje się w adekwatnym „dawaniu” i „otrzymywaniu”, o którym wspomniano wyżej. Nazywa ją równością proporcji; osiąga się ją wtedy, gdy każda strona danej relacji otrzymuje tyle dóbr i przywilejów, ile jest warta. Podział według takiej równości jest podziałem sprawiedliwym, a równość między stronami jest zachowana w przypadku, gdy jest on zastosowany.

Z kolei rozważając, czy w relacji małżeńskiej małżonkowie zawsze muszą dawać sobie to, co powinni, przeciwstawia równość proporcji równości ilości. Równość ilości zachodzi między dwiema ilościami tej samej miary, a równość proporcji - między dwiema proporcjami, np. dwiema podwójnościami ${ }^{32}$. Równość ilościową mają metr sześcienny liści i metr sześcienny wody, a proporcji - dwa liście i dwie krople wody. Rzeczy pozostające ze sobą w relacji równości proporcji nie zawsze są sobie równe ilościowo, podobnie jak rzeczy równe ilościowo nie zawsze są sobie równe proporcjonalnie. Według Tomasza mąż i żona są sobie równi proporcjonalnie, lecz nie ilościowo. Obrazują to dwa przypadki, w których druga relacja nie zachodzi. Po pierwsze, mąż jest lepszy od swojej żony, ponieważ według Akwinaty ma szlachetniejszą rolę w prokreacji - posługując się nomenklaturą Arystotelesa: w jej akcie przekazuje formę, podczas gdy kobieta przekazuje materię ${ }^{33}$. Forma jest elementem substancji, który określa ją poprzez modyfikowanie materii - jej rola jest więc ważniejsza, zatem miejsce w hierarchii jasne. Dla Tomasza aktywność i aktualność jest bardziej wartościowa od bierności i potencjalności, a dychotomia ta jest źródłem pierwszej nierówności ilościowej między mężczyzną a kobietą. Druga pojawia się w narzuceniu kobiecie cechy „rządzonej”, a mężczyźnie - „rządzącego”.

Nie jest do końca jasne, gdzie w tej teorii ujawnia się ilość stanowiąca podstawę domniemanej nierówności, ale można przyjąć, że chodzi o ilość rozumności obecną u przedstawicieli każdej płci biologicznej. Inny problem ujawnia się w pytaniu o to, czy kobieta ma większą wartość w relacji równości ilościowej dotyczącej płodności, skoro według Arystotelesa to ona ma więcej płynów w ciele ${ }^{34}$. Uwagę warto poświęcić również przypadkom, w których brana za pewnik relacja proporcji nie jest spełniona ${ }^{35}$.

\footnotetext{
31 Tomasz z Akwinu, Sententia libri Ethicorum, VIII, q. 7.

32 Tenże, Scriptum super Sententiis, IV, q. 32, a. 1.

33 ST, II-II, q. 26, a. 10.

34 C. McCluskey, An Unequal Relationship Between Equals, dz. cyt., s. 9.

35 Tamże, s. 10-14.
} 


\section{2. „Niewydarzony mężczyzna”}

Badając tomistyczne podejście do kobiet, czyni się to zazwyczaj w odwołaniu do potocznie przypisywanego Akwinacie przekonania, że kobieta jest „niewydarzonym mężczyzną”. Takie podejście wydaje się przekreślać możliwość stricte feministycznej interpretacji jego etyki i stawia badaczkę na bardzo konkretnej ścieżce interpretacyjnej.

Źródłem jest $\mathrm{w}$ tym przypadku q. 92 z części I Summy theologiae, poświęcone utworzeniu kobiety. Tomasz zadaje tu cztery pytania: czy kobieta została powołana do bytu w pierwszym stworzeniu, czy powstała z mężczyzny, a jeśli tak - to czy z jego żebra, i czy została stworzona bezpośrednio przez Boga ${ }^{36}$. W przypadku pierwszego pytania, dotyczącego momentu stworzenia kobiety, słynny epitet pojawia się już w pierwszym argumencie:

Zdaniem Filozofa: „Kobieta jest to mężczyzna niewydarzony”. Lecz w pierwszym ustanowieniu rzeczy nic nie powinno być niewydarzone i niedoszłe. A więc w owym pierwszym ustanowieniu rzeczy kobieta nie powinna być powołana do bytu ${ }^{37}$.

Dalej, w rozwinięciu tego argumentu, pisze:

W odniesieniu do natury partykularnej kobieta jest czymś niedoszłym i niewydarzonym. Czemu? Bo tkwiąca w nasieniu siła czynna zmierza do utworzenia czegoś doskonałego: podobnego do siebie co do płci męskiej. A że rodzi się kobieta, dzieje się to albo z powodu słabości siły czynnej, albo z powodu jakiejś niedyspozycji materii, albo też spowodowało to coś z zewnątrz, np. wiatry południowe, o których [Filozof] pisze, że są wilgotne. Natomiast w odniesieniu do natury powszechnej kobieta nie jest czymś niewydarzonym, ale z zamierzenia natury jest przeznaczona do dzieła rodzenia. A to zamierzenie natury powszechnej zależy od Boga, który jest powszechnym twórcą natury. I dlatego, ustanawiając naturę, powołał do bytu nie tylko mężczyznę, ale i kobietę $e^{38}$.

Kobiecie zostaje zarzucona „niewydarzoność” i „niedoszłość”. Ścisła pejoratywność tych określeń jest jednak mniej oczywista, niż się wydaje; by to zbadać,

36 ST, I, q. 92.

37 ST, I, q. 92, a. 1., t. 7, s. 65.

38 ST, I, q. 92, a. 1, ad 1, s. 66. 
należy odnieść się do tekstu oryginalnego Summy w języku łacińskim. Pierwszy przytoczony fragment brzmi następująco:

Dicit enim philosophus, in libro de Generat. Animal., quod femina est mas occasionatus. Sed nihil occasionatum et deficiens debuit esse in prima rerum institutione $e^{39}$.

Pierwsze zaś zdanie drugiego fragmentu:

[...] per respectum ad naturam particularem, femina est aliquid deficiens et occasionatum $^{40}$.

Polskie tłumaczenia „niewydarzony” i „niedoszły” wzięły się więc z łacińskich occasionatus oraz deficiens. Pierwszy z tych imiesłowów odnosi się do czegoś okazjonalnego, co powstaje w przypadku, gdy zostanie spełniony pewien warunek; czegoś, co powoduje zmianę w jakimś procesie ${ }^{41}$. Drugi można zaś powiązać z czasownikiem deficere, oznaczającym „brakować”. Deficiens można zatem tłumaczyć jako coś, czego dotyczy brak. Choć „coś okazjonalnego” bez wątpienia nie ma tak negatywnego wydźwięku jak „coś naznaczonego brakiem”, to w przypadku tego drugiego można argumentować, że Tomasz i tak nie posłużył się jeszcze bardziej pejoratywnym określeniem, jakim jest defectus, oznaczającym coś uszkodzonego ze względu na fakt nieposiadania czegoś innego ${ }^{42}$.

Dodatkowo należy pamiętać, że w tekście ani razu nie pada wyrażenie „wybrakowany mężczyzna”43: jest za to mowa o „czymś wybrakowanym” i o „okazjonalnym mężczyźnie”. Użycie tego pierwszego sugeruje, że Tomasz nie odbiera kobiecie jej podmiotowości - co uczyniłby w przypadku, gdyby nazwał ją „mężczyzną z jakimś brakiem", wychodząc tym samym z założenia, że istnieje tylko jedna podstawowa płeć, a jej „żeńska manifestacja” pojawia się w momencie, gdy podstawa jest niepełna. A co oznacza drugie sformułowanie?

Tę okazjonalność należy rozumieć dwojako: w wyżej rozwiniętym cytacie kobieta jest okazjonalnym mężczyzną na poziomie partykularnym („W odniesieniu do natury partykularnej kobieta jest czymś [...] niewydarzo-

\footnotetext{
ST, I, q. 92, a. 1.

$40 \quad S T$, I, q. 92, a. 1 , ad 1.

41 M. Trepczyński, T. Ishikawa, Czy kobieta to niewydarzony mężczyzna?, dz. cyt., s. 239.

42 Tamże.

43 Takie sformułowanie przypisuje Tomaszowi np. M. Środa w Czy etyka ma płeć?, „Etyka” 2012, 45, s. 12.
} 
nym”), lecz nie na poziomie powszechnym („Natomiast w odniesieniu do natury powszechnej kobieta nie jest czymś niewydarzonym”). Bierze się to z tego, że według Arystotelesa, którego pogląd przytacza w tym miejscu Tomasz, kobieta rodzi się wtedy, gdy siła czynna obecna w męskim nasieniu jest niewystarczająco silna, by utworzyć coś doskonałego na swój wzór (ewentualnie w przypadku zadziałania czynników zewnętrznych $)^{44}$. $Z$ drugiej strony naturalnym przeznaczeniem kobiety jest rodzenie dzieci, a cel ten został ustanowiony przez Boga jako twórcę całej natury. Kobieta jest zatem czymś jednocześnie niedoskonałym - jako „mężczyzna, który nie doszedł do skutku” - i doskonałym, jako ten element boskiego planu, bez którego nie mogłoby powstawać życie. W tym sensie nie może być bytem okazjonalnym; jest z zasady konieczna.

\subsection{Kobiecy rozum - ratio a intellectus}

Dalej można podejmować próby obrony koncepcji kobiecego rozumu u Akwinaty. Należy bowiem odróżnić rozum (ratio) jako pewną działalność, akt intelektu spełniający się w sądzeniu, od intelektu samego w sobie (intellectus) - rozumienia i pojmowania. Przytoczone wcześniej cytaty, w których pojawiają się wzmianki o rozumie kobiety, w oryginale brzmią następująco:

[...] philosophus loquitur de mulieribus quasi non habentibus iudicium rationis firmum $[\ldots]^{45}$.

Et hoc vel ex defectu rationis, sicut patet in pueris, amentibus et mulieribus $[\ldots]^{46}$.

Ad haec autem mulier sola non sufficit, sed magis in hoc requiritur opus maris, in quo est et ratio perfectior $[\ldots]^{47}$.

Femina enim indiget mare non solum propter generationem, sicut in aliis animalibus, sed etiam propter gubernationem: quia mas est et ratione perfectior $[\ldots]^{48}$.

\footnotetext{
44 Por. M. Nolan, The Aristotelian Background to Aquinas's Denial that «Woman is a Defective Male», „The Thomist” 2000, Vol. 64, No. 1, s. 21-69.

45 ST, II-II, q. 156, a. 1, ad 1.

46 ST, II-II, q. 70, a. 3.

47 SCG, III, q. 122 , a. 8.

48 SCG, III, q. 123, a. 3.
} 
O ile kobieta jest „tylko” niezrealizowanym mężczyzną w sensie swojej cielesności (femina est aliquid deficiens et occasionatum), o tyle w przypadku rozumu działalność jej racjonalności jest defecta, uszkodzona, nieposiadająca czegoś, rozum męski zaś - perfectior. Należy jednak pamiętać, że Tomasz postrzega i wartościuje rozum zupełnie inaczej niż dzisiejsi myśliciele i myślicielki.

Intellectus oznacza przede wszystkim trwałą dyspozycję doskonalącą władzę poznania niematerialnego i cnotę poznania pierwszych prawd, a także zdolność do poznania prostego i/lub (w zależności od kontekstu) dyskursywnego ${ }^{49}$. Jest najważniejszą i najszlachetniejszą władzą poznawczą. Spełnia trzy funkcje: tworzy pojęcia, przeprowadza sądy i rozumuje (czyli przechodzi z jednego do drugiego, processus de uno in aliud $)^{50}$.

Rozum (ratio) to spełnianie tej trzeciej funkcji i nie należy go mylić z intelektem jako takim. Oznacza stosowanie władzy poznawczej w odniesieniu do szczegółowej, zmysłowej władzy duszy (ratio particularis) lub do niematerialnej władzy duszy ${ }^{51}$. Sferę ratio, pozostającą w związku z cielesnością i zmysłowością, Tomasz opisuje jako najniższą, najbardziej charakterystyczną dla człowieka. Jej zaistnienie odróżnia go od zwierząt, lecz w porównaniu do Boga i aniołów jest ona niedoskonała, słaba (infirma) - nie zakłada prostego poznania, lecz zawiłe rozumowania, które narażone są na błąd. W świetle przyjęcia przez Tomasza przesłanek dotyczących kobiecej cielesności nie dziwi więc wskazanie, że jej rozum związany z cielesnością jest defectus. Co istotne, tak ma się rzecz nawet $\mathrm{z}$ rozumem męskim, który w porównaniu do duchów czystych również występuje w zalążkowym stopniu ${ }^{52}$. Poza tym Tomasz pisze o ratio jako o pewnej aktualizacji; słabość dotycząca rozumowań kobiety nie dotyczy więc słabości w umiejętności rozumowego działania, czyli w potencji, lecz w jej aktualizacji - działaniu ${ }^{53}$.

49 M. Penczek, Wola i intelekt w filozofii Tomasza z Akwinu, Wydawnictwo Uniwersytetu Jagiellońskiego, Kraków 2012, s. 15-16.

50 S. Swieżawski we wstępie do kwestii 79 Traktatu o człowieku, Wydawnictwo Antyk, Kęty 2000, s. 273.

51 M. Penczek, Wola i intelekt w filozofii Tomasza $z$ Akwinu, dz. cyt., s. 16-17.

52 S. Swieżawski, dz. cyt.

53 Zarówno ratio, jak i intellectus mogą przybierać u Tomasza różne znaczenia - ratio może być particularis, a także universalitatis (por. Quaestio disputata de spiritualibus creaturis, 9.6), podczas gdy intellectus może oznaczać nie tylko intelekt, ale i pojęcie czy rozumienie. Oprócz intelektu możnościowego Tomasz wymienia również intelekt czynny, który jest aktem. Wobec tego przedstawianie dychotomii ratio-intellectus jako możność-akt nie zawsze jest poprawne. Wydaje się jednak, że w przypadkach nakreślonych przez Tomasza to właśnie ratio oznacza działanie. 
To w działaniu kobiety, podobnie jak dzieci, mają gorzej używać rozumu. Takie przekonanie Tomasza bazuje raczej na jego własnym doświadczeniu i stereotypie $^{54}$, który najprawdopodobniej ujmuje kobiecie część rozumności na rzecz emocjonalności. Ostatecznie kluczowe jest to, że w wyższych, duchowych operacjach intellectus, dzięki którym człowiek zbliża się intelektualnie do Boga - co stanowi dla Akwinaty cel ludzkiej egzystencji - kobieta nie jest w żaden sposób gorsza od mężczyzny.

\subsection{Imago Dei}

Inny problem wiąże się z kwestią imago Dei - zarówno kobieta, jak i mężczyzna, jako (w różnym stopniu) racjonalne istoty zostali stworzeni na podobieństwo Boga - Pana całego stworzenia - ale według Akwinaty to mężczyzna, jako głowa rodziny i pan swojej żony, jest jego pełniejszym obrazem ${ }^{55}$. Tomasz wyróżnia dwa rodzaje ludzkiego podobieństwa do Boga $\mathrm{i}$, analogicznie, jeden $\mathrm{z}$ nich odnosi zarówno do kobiety, jak i mężczyzny, a drugi wyłącznie do mężczyzny. W q. 93 z I części Summy theologiae, następującym bezpośrednio po tym, w którym pojawia się niesławny „niewydarzony mężczyzna”, w jednym $z$ artykułów stawia pytanie o to, czy w każdym człowieku widnieje obraz Boga. Zasadniczą podstawę średniowiecznego sporu o stworzenie kobiety na obraz Boga stanowi niezgodność pomiędzy dwoma cytatami z Biblii. Pierwszy z nich pochodzi z Księgi Rodzaju i poucza, że Bóg stworzył na swój obraz „całego” człowieka, zarówno mężczyznę, jak i kobietę ( $\operatorname{Rdz} 1,27)$. Drugi fragment pochodzi z Listu do Koryntian św. Pawła, w którym ten rozważa, dlaczego mężczyzna nie powinien nakrywać głowy, a kobieta już tak - apostoł dochodzi do wniosku, że mężczyzna jest „obrazem i chwałą Boga", podczas gdy kobieta jest chwałą mężczyzny (1 Kor 11,7). Pisze dalej, że po pierwsze to nie mężczyzna powstał z kobiety, lecz kobieta z mężczyzny, a po drugie kobieta została stworzona dla mężczyzny, nie odwrotnie, dlatego w przeciwieństwie do niego powinna zakrywać głowę. Tomasz przywołuje ten element Listu do Koryntian i odpowiada przecząco na postawione sobie pytanie - skoro kobieta jest człowiekiem i „obrazem-chwałą” mężczyzny, czyli skądinąd

54 O problemie edukacji dziewcząt i kobiet w średniowieczu por. J.M. Ferrante, The education of women in the Middle Ages in theory, fact, and fantasy, w: Beyond Their Sex: Learned Women of the European Past, ed. P.H. Labalme, New York University Press, New York 1980, s. 9-42.

55 I. Serrano del Pozo, Algo imperfecto y ocasional. Una relectura a la controvertida tesis de Tomás de Aquino sobre la mujer, „Divus Thomas” 2018, Vol. 121, No. 3, s. 276. 
nie partycypuje w obrazie Boga, to nie wszyscy ludzie w nim partycypują. Nie jest to oczywiście jego ostateczna odpowiedź:

Zarówno w mężczyźnie, jak i w kobiecie widnieje obraz Boga ze względu na to, w czym głównie ziszcza się treść obrazu, mianowicie ze względu na naturę myślącą. Stąd też Pismo św. po słowach: „Na obraz Boży go stworzył” - tzn. człowieka, zaraz dodaje: „Mężczyznę i niewiastę, stworzył ich”: i w liczbie mnogiej mówi: ich - jak zauważa Augustyn, żeby nie myślano, iż w jednej osobie obie płci zostały połączone. Pod jakimś jednak ubocznym względem w taki sposób obraz Boga znajduje się w mężczyźnie, w jaki nie znajduje się w kobiecie: bo mianowicie mężczyzna jest początkiem i celem kobiety, tak jak Bóg jest początkiem i celem całego stworzenia. Stąd też Apostoł po słowach: „Mężczyzna ... jest obrazem i chwałą Boga, a kobieta jest chwałą mężczyzny”, uzasadnia to twierdzenie, dodając: „To nie mężczyzna powstał z kobiety, lecz kobieta z mężczyzny. Podobnie też mężczyzna nie został stworzony dla kobiety, ale kobieta dla mężczyzny"56.

Tomasz przyjmuje udział kobiety w imago Dei na jej duchowym poziomie, lecz odrzuca na cielesnym. Wynika to z tego, że czysta cielesność kobiety podporządkowana jest prokreacji; $z$ takiej teleologii wynika jej poddańczość. Akwinata przyjmuje także hierarchię określającą mężczyznę jako nadrzędnego wobec kobiety, na podobieństwo Boga jako nadrzędnego wobec całego stworzenia, oraz uzupełnia tę koncepcję o wysunięcie postulatu, w ramach którego mężczyzna jest początkiem i celem kobiety.

\section{4. Źródła feministycznej obrony Tomasza}

Feministyczne próby odczytania Tomasza mogą mieć swoje podłoże w różnych elementach jego doktryny. Jedno z podejść, oparte na przesłankach ontologicznych, podkreśla, że dla Akwinaty kobieta jest osobą - duchowym stworzeniem, celem samym w sobie, a nie środkiem do innych celów. Ma zapewnioną przez Boga indywidualność, z czego ściśle wynika jej osobowość,

56 ST, I, q. 93 , a. 4 , t. 7, s. 75. 
podmiotowość ${ }^{57}$. Jako metafizyczna całość ma dostęp do swojej indywidualnej rzeczywistości. Jest ważniejsza od rzeczy, które są tylko środkami do innych celów, a nawet od własnej seksualności (która związana jest przecież z płodnością), ponieważ oprócz ciała ma także duszę, a wartość danej przez Boga duchowości przewyższa cały materialny świat i stanowi o godności kobiety oraz o jej statusie jako istoty o racjonalnym charakterze.

Interesujące jest również zagadnienie zależności. Obierając perspektywę teocentryczną, można przyjąć, że zależność pochodzi od Boga, wobec czego kobieta i przypisywana jej cielesna słabość obrazują nie tylko zależność od innych ludzi, lecz także boską moc jako jedyną siłę zdolną do wyrwania materii z jej naturalnej kruchości ${ }^{58}$. Tomasz zastanawia się, czy ciała kobiet zachowują po zmartwychwstaniu swoją płeć, zważywszy, że pojawiają się wtedy w całej swojej doskonałości. Odpowiada twierdząco - cielesna wątłość kobiety nie jest spowodowana przez wadę materii, lecz stanowi wrażliwość, daną jej przez naturę jako element boskiej mądrości, a jej odmienność od mężczyzny jest dowodem doskonałości natury $^{59}$. Takie podejście odróżnia go od Arystotelesa, który w świecie dostrzega głównie słabość materii. Akwinata zdaje się bowiem wychodzić z założenia, że w tej słabości objawia się potrzeba boskiej łaski - kobieca „niewydarzoność” może być zatem najdoskonalszym obrazem kondycji ludzi jako istot zależnych i wrażliwych.

Inną linią pogodzenia myśli tomistycznej $\mathrm{z}$ feministyczną jest wskazanie na zagadnienie emocji - o ile przyjmiemy mało atrakcyjne dzisiaj założenie, że myśl feministyczna opiera się właśnie na głębokiej, bezkompromisowej afirmacji emocjonalności i niejako niechęci do stałości oraz racjonalności w jej najczystszej formie ${ }^{60}$. W teorii chrześcijańskiej rozum nie musi kłócić się z emocjami, ponieważ sam je w pewnej formie afirmuje - jako akty woli, która stanowi z kolei pewną racjonalną dążność. Tak rozumiane emocje (affecti) to coś innego niż uczucia

57 J. Hartel, The Integral Feminism of St. Thomas Aquinas, „Gregorianum” 1996, Vol. 77, No. 3, s. 545.

58 I. Serrano del Pozo, Algo imperfecto y ocasional, dz. cyt., s. 279.

59 SCG, IV.88.3.

60 Por. P. Lichacz, O łączeniu myśli feministycznej z tomistyczną, „Studia Antyczne i Mediewistyczne" 2014, 12 [47], s. 139-151. Kwestią głęboko problematyczną w tym artykule jest postawienie tezy o domniemanym charakterystycznym dla feminizmu „rozemocjonowanym dyskursie”, „wnioskach wyciąganych nie wiadomo skąd” i „roszczeniowych postawach”, które mają stanowić stereotypy dotyczące myśli feministycznej. 
(passiones). Pejoratywne emocje, które podlegają rozumowi i są przez niego opanowywane, to wyłącznie gwałtowne namiętności i furie ${ }^{61}$.

Wartościowe i oryginalne jest zwrócenie uwagi na możliwość integracji lex naturalis Tomasza $\mathrm{z}$ feministyczną teorią cnoty. Ta druga ma być oparta na pluralizmie doświadczeń, dynamizmie i spontaniczności, podczas gdy prawo naturalne jest raczej nastawione na stałość i jedność, z których wynikają uniwersalność i trwałość zasad moralnych ${ }^{62}$. Choć pogodzenie tych dwóch postaw wydaje się skazane na porażkę, to próbowano tego dokonać np. poprzez zwrócenie uwagi na sposób, w jaki tomistyczne pojmowanie etyki cnoty i prawa naturalnego różnią się od tych formułowanych przez późniejszych myślicieli ${ }^{63}$.

Współczesny feminizm intersekcjonalny przyjmuje antykoncepcję jako środek, dzięki któremu osoby z żeńskimi organami płciowymi mogą kontrolować swoje ciała, jest w nim również obecna ciepła afirmacja nieheteronormatywnych orientacji seksualnych i płciowych. O ile kwestia antykoncepcji pozostaje problematyczna ${ }^{64}$, o tyle podejmuje się próby mające na celu wykazanie, że tomizm nie stoi w sprzeczności z akceptacją homoseksualności w chrześcijaństwie ${ }^{65}$. Źródłem niniejszej akceptacji miałoby być przyjęcie paradygmatu, w ramach którego niektóre osoby doznają przyjemności w rzeczach niezgodnych $\mathrm{z}$ naturą ogólną człowieka (jak zostaje określona homoseksualność), które wynikając z ich natury indywidualnej, są jednak naturalne, a więc i dobre. Co więcej, homoseksualność ma być zakorzeniona $\mathrm{w}$ duszy ${ }^{66}$ jako pewne przyzwyczajenie (consuetudo), co umożliwia $\mathrm{z}$ kolei skonstruowanie tomistycznej koncepcji płci kulturowej ${ }^{67}$. Akt miłości nieheteroseksualnej pozbawiony jest grzechu o tyle, o ile jest zrealizowany w miłości i dobroduszności ${ }^{68}$.

\footnotetext{
61 Tamże, s. 146.

62 Tamże, s. 149.

63 Por. P. Hall, Narrative and the Natural Law: An Interpretation of Thomistic Ethics, Notre Dame, Indiana 1994.

64 O negatywnym aspekcie antykoncepcji w myśli tomistycznej por. W.F. Murphy, Revisiting Contraception: An Integrated Approach in Light of the Renewal of Thomistic Virtue Ethics, „Theological Studies" 2011, Vol. 72, No. 4, s. 812-847.

65 Por. K. Grimes, Butler Interprets Aquinas. How to Speak Thomistically About Sex, „The Journal of Religious Ethics" 2014, Vol. 42, No. 2, s. 187-215.

66 A. Oliva, Amours. L'Église, les divorcés remariés, les couples homosexuels, Les Éditions du Cerf, Paris 2015, s. 78 (a także 81, 90-91, 93-94).

67 Tamże, s. 80.

68 Tamże, s. 113.
} 
Należy jednak wskazać na problem z przyjęciem tego rozwiązania. Wynika on $\mathrm{z}$ tego, że Tomasz explicite potępia stosunki homoseksualne (coitus masculorum) jako nie tylko sprzeczne $\mathrm{z}$ naturą ${ }^{69}$, ale i występujące $\mathrm{w}$ zepsutej naturze jednostkowej z powodu zepsucia zasad natury, a więc na tym (zepsutym) poziomie współnaturalne (connaturales) ze sobą ${ }^{70}$. Według niektórych badaczy, afirmując homoseksualność na tym szczeblu doktryny Tomasza, należy afirmować dodatkowo inne wymienione przez niego negatywne „skłonności”: kanibalizm i zoofilię ${ }^{71}$. Źródłem zestawienia tych trzech przypadków jest zauważenie przez Tomasza, że wszystkie one spotykane są tylko u ludzi, jako nawyki (już w negatywnym sensie ${ }^{72}$ ). Na pierwszy rzut oka taką argumentację można odrzucić, opierając się na współczesnej wiedzy naukowej, zgodnie z którą zarówno u zwierząt i roślin, jak i u ludzi można zaobserwować nie tylko homoseksualnośćc73, ale i transpłciowość ${ }^{74}-\mathrm{z}$ definicji mogłyby to zatem być cechy zgodne $\mathrm{z}$ tomistyczną naturą (secundum naturam). Nie jest to jednak takie proste, ponieważ Tomaszowa „natura” ma dwa znaczenia: to, że coś występuje $w$ naturze rozumianej jako przyroda, nie oznacza, że jest zgodne z naturą. W orzekaniu, czy coś jest zgodne z naturą, najważniejszym czynnikiem jest rozumność (a nie zajście w przyrodzie spontanicznych mechanizmów biologicznych) - właśnie w kontekście rozumności Tomasz uznaje za nienaturalne wyżej wymienione „skłonności”. Nie uznaje bynajmniej, że obserwowalność czegoś w świecie natury wystarcza do aprobaty moralnej, a więc i uznania tej rzeczy za „naturalną”. Pomieszanie tych dwóch „natur” w obrębie myśli Akwinaty skutkuje ekwiwokacją.

Warto $\mathrm{w}$ końcu przytoczyć niezwykle ważny z perspektywy myśli feministycznej element prezentowanej tu koncepcji Akwinaty, wyrażony przezeń

69 Por. Tomasz z Akwinu, ST, I.II.31.7 i II-II.154.11 lub Super Epistolam S. Pauli ad Romanos lectu$r a, 1.8$.

70 A. Andrzejuk, Tomistyczna «La Révolution Sexuelle» O. Adriano Olivy OP, „Studia Theologica Varsaviensia" 2016, nr 1, s. 238.

71 Tamże. Taki pogląd, mający na celu wykazanie absurdu akceptacji homoseksualności, przytacza Autor za B. Blankenhornem, C.J. Droste, E. Jindráčkiem, D. Leggem i T.J. Whitem, którzy wystosowali odpowiedź na Amours Olivy (http://www.libertepolitique.com/Actualite/Decryptage/ Un-thomisme-gay-Cinq-dominicains-repondent-a-Adriano-Oliva).

72 Tamże, s. 240-241.

73 Por. Sommer V., ed., Homosexual Behaviour in Animals. An Evolutionary Perspective, Cambridge University Press, Cambridge 2006 oraz dla analizy filozoficznej: P.R. Adriaens, In Defence of Animal Homosexuality, „Philosophy, Theory, and Practice in Biology” 2019, Vol. 11(22), s. 1-19.

74 Por. R. Vega-Frutis, R. Macias-Ordoñez, R. Guevara, L. Fromhage, Sex change in plants and animals: a unified perspective, „Journal of Evolutionary Biology” 2014, nr 27, s. 667-675. 
w sposób niebudzący wątpliwości interpretacyjnych, a mianowicie potępienie przestępstwa raptus, polegającego na porywaniu kobiet w celu zmuszenia ich do zawarcia małżeństwa ${ }^{75}$. Tomasz nie tylko odnosi się do przepisu prawa kanonicznego mającego na celu ochronę kobiet przed przymusowymi małżeństwami ${ }^{76}$, lecz także stwierdza, że przestępstwo to zostaje popełnione nawet w wypadku, gdy dana kobieta nie została zgwałcona ${ }^{77}$. Uprowadzenie kobiety w celu odbycia z nią wymuszonego stosunku seksualnego jest zatem czynem karalnym nawet w przypadku, gdy do takowego nie dojdzie. Tomasz wykazuje aprobatę wobec prawa, które zakłada, że jakakolwiek pozorna zgoda na współżycie w takich okolicznościach nie jest prawdziwą zgodą i czyni każdą próbę zawarcia związku małżeńskiego nieważną, a sam czyn - wykroczeniem.

\section{Współczesny feminizm tomistyczny}

Po soborze watykańskim II wyłoniły się trzy nurty stanowiące modele teologiczne i tradycyjne, których celem było zajęcie się problematyką kobiecą: augustiański, neofranciszkański oraz neotomistyczny ${ }^{78}$. Największą popularnością cieszy się właśnie model neotomistyczny ${ }^{79}$, w którym zwraca się uwage na obecność świadomości historycznej, w ramach której ludzkie rozumienie prawdy nieustannie się rozwija i nie jest czymś, co już zostało zakończone. Prawda cechuje się oczywiście obiektywnością, lecz jest przez człowieka ujmowana stopniowo ${ }^{80}$. Podobnym procesom podlegają nauki o moralności religijnej ${ }^{81}$. Taka koncepcja epistemologiczna ma ogromne znaczenie w dziedzinie analizy koncepcji płci i płciowości,

75 M. Nolan, Aquinas and the Act of Love, „New Blackfriars” 1996, Vol. 77, No. 902, s. 116.

76 ST, II-II, q. 154, a. 1.

77 Tamże.

78 Te modele spotkały się z największym uznaniem na Zachodzie; równolegle zaczęly powstawać chrześcijańskie etyki feministyczne w wariacjach latynoskich, azjatyckich oraz afrykańskich, które mniej inspirowały się naukami św. Augustyna, św. Franciszka i św. Tomasza, a więcej biblijną postacią Junii/Juniasza - osoby o nieokreślonej w Biblii płci, będącej prawdopodobnie apostołem.

79 L. Sowle Cahill, Catholic Feminists and Traditions: Renewal, „Journal of the Society of Christian Ethics" 2014, Vol. 34, No. 2, s. 32.

80 J.F. Keenan, A History of Catholic Moral Theology in the Twentieth Century: From Confessing Sins to Liberating Consciences, Continuum, London 2010, s. 113.

81 R.R. Gaillardetz, The Groupe des Dombes Document "One Teacher" (2005): Toward a Postconciliar Catholic Reception, „Theological Studies” 2013, Vol. 74, No. 1, s. 45. 
która odrzuca niedające się uzasadnić naukowo esencjalistyczne teorie prawa naturalnego, mające swoje podłoże w domniemanie stałej ludzkiej naturze ${ }^{82}$. Wobec takich założeń kobiety powinny podejmować aktywne działania mające na celu kształtowanie nowych tradycji w swoich społecznościach i „odświeżenie” filozofii moralnej poprzez czerpanie ze swoich własnych doświadczeń w sposób, który przemówi do chrześcijanek znajdujących się w przeróżnych okolicznościach ${ }^{83}$.

Progresywny feminizm neotomistyczny kładzie nacisk na nauczanie m.in. w dziedzinach seksualności i płciowości ${ }^{84}$. Czyni to poprzez syntezę teorii Akwinaty z naukami oraz nowymi paradygmatami i doświadczeniami płci - chociaż Tomasz $\mathrm{z}$ jednej strony ocenia kobietę jako mniej racjonalną od mężczyzny, a $z$ drugiej uwydatnia wage jej roli w akcie prokreacji, to przyznaje, że po pierwsze w obrębie duchowości jest mu równa, a po drugie jednym z celów małżeństwa jest głęboka przyjaźń. Poza tym prokreacyjny cel małżeństwa jest najlepiej realizowany w przypadku, gdy jego osoby znajdują się w stanie miłości i wsparcia, który wymaga od nich z kolei częstszego współżycia niż byłoby potrzebne dla samej prokreacji ${ }^{85}$. Otwiera to dyskurs na podjęcie wątku o etycznym aspekcie antykoncepcji, seksu, przyjemności i intymności seksualnej. Rzeczywiste zło w zachowaniach seksualnych nie pochodzi z seksu, którego celem nie jest prokreacja, lecz z przemocy wobec kobiet - formy zła zakorzenionej w nierówności płciowej $^{86}$.

Szczególna uwaga zostaje zwrócona na nierówności ekonomiczne w rodzinie ${ }^{87}$. Doszukuje się w Tomaszu sojusznika równości płciowej - prawo naturalne powinno brać pod uwagę rozwój kobiet jako element ostatecznego celu ludzkości, jakim jest spełnienie w Bogu ${ }^{88}$. Celem etyki neotomistycznej jest w gruncie rzeczy oddanie głosu tym, którzy wcześniej go nie mieli (nie tylko kobietom, ale i oso-

82 J. Clague, Gender and Moral Theology: A Shared Project, w: Catholic Theological Ethics: Past Present, and Future, ed. J. F. Keenan, Orbis Books, Maryknoll, New York 2011, s. 288.

83 B.H. Andolsen, Whose Sexuality? Whose Tradition? Women, Experience, and Roman Catholic Sexual Ethics, w: Feminist Ethics and the Catholic Moral Tradition, ed. C.E. Curran, M.A. Farley, R.A. McCormick, Paulist Press, New York 1996, s. 208.

84 L. Sowle Cahill, Catholic Feminists and Traditions: Renewal, dz. cyt., s. 33.

85 Por. L. Fullam, Toward a Virtue Ethics of Marriage: Augustine and Aquinas on Friendship in Marriage, „Theological Studies” 2012, Vol. 73, No. 3, s. 663-692.

86 B.H. Andolsen, Whose Sexuality? Whose Tradition?, dz. cyt., s. 225.

87 Por. C. Firer Hinze, Women, Families, and the Legacy of Laborem Exercens: A finished Agenda, "Journal of Catholic Social Thought" 2009, Vol. 6, No. 1, s. 63-92.

88 Por. C.L.H. Traina, Feminist Ethics and Natural Law: The End of the Anathemas, Georgetown University Press, Washington, DC 1999. 
bom o kolorze skóry innym niż biały i orientacjach nieheteronormatywnych), oraz przypisanie ważnej roli relacjom międzyludzkim i związanym z nimi codziennym doświadczeniom jako aktom i stanom nie prywatnym, lecz ogólnym, wpływającym na wspólne dobro człowieczeństwa - w ten sposób ma się konsty tuować lex naturalis. Czyni się to głównie przez odrzucenie Arystotelesowskiej biologii na rzecz współczesnej wiedzy naukowej ${ }^{89}$. Wiele autorek pisze, że wspólne dobro, sprawiedliwość i relacja z Bogiem mogą być realizowane przez związki osób tej samej płci ${ }^{90}$. Istnieją interpretacje myśli Tomasza, które wykazują, że nie stoi ona $\mathrm{w}$ sprzeczności z kontrowersyjnym postulatem umożliwienia kobietom sprawowania kapłaństwa ${ }^{91}$. Obecnie najbardziej wpływową etyczką feministyczną działającą w nurcie neotomistycznym jest Margaret Farley, która wyróżnia siedem zasad seksualności, będących odbiciem tradycji prawa naturalnego: zakaz czynienia krzywd, wolną zgodę, wzajemność, równość, zaangażowanie, płodność (w znaczeniu wydajności) i sprawiedliwość społeczną ${ }^{92}$.

\section{Podsumowanie}

Istnieje znana anegdota z życia „Milczącego Woła”, obrazująca przypisywaną mu niechęć do kobiet. Jego bracia mieli zamknąć go w wieży i tam nasłać nań nagą kobietę, aby powstrzymać go przed wstąpieniem do zakonu dominikanów, który uchodził wówczas za mało prestiżowy - Tomasz przegonił ją jednak pochodniąa ${ }^{93}$. Ponoć „unikał kobiet jak żmij, o ile nie było to absolutnie potrzebne” ${ }^{\text {. }}$.

Formułowane przez niego opinie dotyczące kobiecości, wyrażane na przestrzeni wielu dzieł, nie cechują się jednak tego typu zgodnością. Choć za Arystotelesem nazywa kobietę „okazjonalnym mężczyzną”, okazjonalność ta dotyczy wyłącznie sfery jednostkowo-przyrodniczej; w kontekście ogólnoprzyrodniczym i teolo-

\section{Sowle Cahill, Catholic Feminists and Traditions: Renewal, s. 34.}

90 Por. Firer Hinze C., Hornbeck II J.P., ed., More than a Monologue: Sexual Diversity and the Catholic Church, Vol. 1, Voices of Our Times oraz Vol. 2, Inquiry, Thought and Expression, Fordham University Press, New York 2014.

91 Por. J. Miller, A Note On Aquinas: And Ordination Of Women, „New Blackfriars” 1980, Vol. 61, No. 719, s. 185-190.

92 M.A. Farley, Just Love: A Framework for Christian Sexual Ethics, Continuum, New York 2006, s. 215-232.

93 U. Eco, In Praise of Thomas Aquinas, „The Wilson Quarterly” 1986, Vol. 10, No. 4, s. 80.

94 Tamże. 
gicznym odrzuca ją poprzez przyznanie kobiecie istotnej roli w boskim planie. Utrzymuje, że kobieta jest mniej racjonalna od mężczyzny (chociaż jego rozumienie racjonalności nie do końca pokrywa się ze współczesnym), lecz zarazem stawia ją z nim w relacji równości - rozróżniając dwa rodzaje równości, twierdzi, że równość między nimi polega na proporcji, lecz nie na ilości, przy czym należy jednak zauważyć, że ta relacja może zaistnieć wyłącznie w małżeństwie. Chociaż Tomasz wiele czerpie z Arystotelesa (przez co zakłada defektywną racjonalność kobiety, jej naturalne poddaństwo wobec mężczyzny oraz zasadę równości nierównych), to nie zgadza się z nim we wszystkich aspektach: mówi o inherentnej słabości kobiety, którą i tak postulowała większość średniowiecza ${ }^{95}$, ale nie idzie dalej i nie oskarża jej o złośliwość, zazdrość, kłótliwość, kłamliwość, brak wstydu i szacunku do siebie samej. Wręcz przeciwnie: podkreślając jej prawo do dobrowolnego zawierania małżeństwa i przestępczość aktu raptus, zwraca uwagę na jej godność. Czyni to także przez podkreślanie roli, jaką w małżeństwie pełni przyjaźń. W tym zakresie Akwinata wykracza poza nauczanie Arystotelesa.

Niniejszy artykuł wyszedł poza analizę klasycznego już zagadnienia kobiecości przedstawionego w q. 92 części I Summy theologiae poprzez krytyczne porównanie myśli Tomaszowej z Arystotelesową (z którą jest ona zazwyczaj zestawiana), podjęcie próby obrony kobiecego rozumu i wskazanie na nieoczywiste wątki obecne w koncepcji małżeństwa Akwinaty (prokreacja jest jego drugorzędnym celem, ustępuje bowiem przyjaźni, a męska poligamia jest niesprawiedliwa dla kobiet). Wskazano na wątki, które można wymienić jako spójne z pewnymi nurtami feminizmu (doskonałość kobiety jako elementu boskiego planu, jej „cielesną wątłość” daną z natury jako element boskiej mądrości, a więc niespowodowaną przez wadę materii, równość mężczyźnie w wyższych operacjach intelektu, podkreślenie jej natury myślącej i indywidualności jako bytu duchowego, co bezsprzecznie stanowi o jej godności) i te, które pozostają problematyczne (kobiece „uleganie pasjom”, uszkodzone ratio, które jest jednak infirmus nawet u mężczyzny, niewystarczające kompetencje do samodzielnego wychowywania własnych dzieci, naturalną podległość wobec mężczyzny i związaną z tym niepełną realizację imago Dei, pewnego rodzaju „okazjonalność” i „niedoszłość, dziwnie skonstruowaną równość z mężczyzną, traktowanie macierzyństwa jako zasadniczej cechy kobiecości oraz potępienie explicite homoseksualności). Przy-

95 Por. K.K. Staples, Medieval Europe, w: A Companion to Global Gender History, ed. T.A. Meade, M.E. Wiesner-Hanks, Wiley-Blackwell, Hoboken 2021. 
toczone zostały pewne osiągnięcia współczesnego feminizmu tomistycznego i elementy, w których te dwa obszary mogą szukać porozumienia (uznawanie rozwodów małżeństw, w których nie ma przyjaźni, porzucenie arystotelowskiej biologii, oddanie głosu mniejszościom, określenie prawdy i wiedzy o moralności jako czegoś, co poznaje się stadialnie). Zwrócono także uwagę na możliwość feministycznej interpretacji koncepcji lex naturalis, które powinno obejmować dobrostan kobiet i mniejszości.

Ze względu na rolę Akwinaty w ukształtowaniu tradycji chrześcijańskiej zdecydowanie warto podejmować próby feministycznego odczytania jego tekstów - należy jednak pamiętać, że w przypadku myśliciela żyjącego prawie osiemset lat temu nie będzie to łatwym zadaniem. Można to czynić na poziomie lingwistycznym (analizując pojęcie „niewydarzonego mężczyzny” i rozróżniając ratio, które u kobiety ma być uszkodzone, od intellectus), ontologicznym (wskazując na doskonałość cielesnej konstytucji kobiety, jej rolę w akcie stworzenia i duchową podmiotowość) oraz krytycznym. Biorąc pod uwagę wszystkie wymienione wyżej przekonania, myśl Tomasza, między innymi przyznającego kobiecie ten sam poziom duchowości, co mężczyźnie, może okazać się żyznym gruntem dla chrześcijańskiego feminizmu.

Pogłębiona, obszerna analiza feministycznego aspektu myśli Tomasza z Akwinu wiąże się nieuchronnie $\mathrm{z}$ analizą pojęcia kobiecości. Ta $\mathrm{z}$ kolei wpłynie na definicję przyjmowanego feminizmu. Wobec tego należy próbować odpowiedzieć na pytanie o to, czym się kobiecość cechuje i jaka jest jej natura - czy chcemy doszukiwać się dla niej stałej, powszechnej definicji, czy jednak otworzyć na to, aby każda osoba czująca się kobietą mogła ją skonstruować samodzielnie, według własnej miary? Czy kobiecość musi wiązać się z tradycyjnie przyjmowanymi wartościami płciowymi - na gruncie których można ją łączyć z „troskliwą" stroną etyki tomistycznej i wyrażoną w niej afirmacją roli macierzyństwa w akcie stworzenia - czy też być czymś zupełnie innym?

Ostatecznie Tomasz nie pisze o płci jako takiej ${ }^{96}$, nie podejmuje też na poważnie problematyki podrzędności kobiet, która w jego czasach jest czymś niekwestionowanym. Zło, jakie dostrzega w relacjach seksualnych feminizm tomistyczny, wiąże się z przemocą i nierównością, które powinny być niwelowane przez egzekwowane prawo naturalne. Pamiętając o tym, można wyzwolić się z płyt-

96 Por. J. Finley, The Metaphysics of Gender: A Thomistic Approach, „The Thomist: A Speculative Quarterly Review" 2015, Vol. 79, No. 4, s. 585-614. 
kich i upraszczających wizji teorii Tomasza i otworzyć się na podjęcie na jej gruncie praktyki feministycznej.

\section{Bibliografia}

\section{Źródła:}

Arystoteles, Generation of Animals, trans. A.L. Peck, Harvard University Press, Harvard 1942.

Arystoteles, De generatione animalium, w: tegoż, Opera, ed. I. Bekkeri, t. V, Oxford University Press, Oxford 1837.

Arystoteles, Etyka nikomachejska, tłum. D. Gromska, PWN, Warszawa 1982.

Arystoteles, O rodzeniu się zwierzat, tłum. P. Siwek, PWN, Warszawa 1979.

Arystoteles, Polityka, tłum. L. Piotrowicz, PWN, Warszawa 1964.

Arystoteles, Zoologia, tłum. P. Siwek, PWN, Warszawa 1982.

Tomasz z Akwinu, Quaestio disputata de spiritualibus creaturis, Marietti, Taurini-Romae 1953, www.corpusthomisticum.org.

Tomasz z Akwinu, Scriptum super Sententiis, Parmae 1856, www.corpusthomisticum.org.

Tomasz z Akwinu, Sententia libri Ethicorum, Commissio leonina, Romae 1969, www.corpusthomisticum.org.

Tomasz z Akwinu, Summa contra Gentiles, Marietti, Taurini-Romae 1961, www.corpusthomisticum.org.

Tomasz z Akwinu, Summa Theologiae, Ex Typographia Polyglotta, Romae 1888, www.corpusthomisticum.org.

Tomasz z Akwinu, Super Epistolam S. Pauli ad Romanos lectura, Taurini 1953, www.corpusthomisticum.org.

Tomasz z Akwinu, Summa contra Gentiles. Prawda wiary chrześcijańskiej, tłum. Z. Włodek i W. Zega, Wydawnictwo W drodze, t. 1, Poznań 2003, t. 2, Poznań 2007, t. 3.

Tomasz z Akwinu, Suma teologiczna, tłum. P. Bełch, Veritas, Londyn 1963.

Tomasz z Akwinu, Traktat o człowieku, tłum. S. Swieżawski, Wydawnictwo Antyk, Kęty 2000. 


\section{Opracowania:}

Adamiak E., Kobieta w Kościołach i wspólnotach chrześcijańskich. Próba syntezy teologicznej, „Poznańskie Studia Teologiczne” 2001, t. 11, s. 91-114, URL: https://repozytorium.amu.edu.pl/bitstream/10593/8362/1/06_Elzbieta_Adamiak_Kobieta\%20w\%20Ko\%C5\%9Bcio\%C5\%82ach\%20i\%20wsp\%C3\%B31notach\%20chrze\%C5\%9Bcija\%C5\%84skich_91-114.pdf.

Adriaens P.R., In Defence of Animal Homosexuality, „Philosophy, Theory, and Practice in Biology" 2019, Vol. 11(22), s. 1-19,

https://doi.org/10.3998/ptpbio.16039257.0011.022.

Andolsen B.H., Whose Sexuality? Whose Tradition? Women, Experience, and Roman Catholic Sexual Ethics, w: Feminist Ethics and the Catholic Moral Tradition, ed. C. E.Curran, M.A. Farley, R.A. McCormick, Paulist Press, New York 1996, https://doi.org/10.1007/978-94-015-7963-6_4.

Andrzejuk A., Tomistyczna «La Révolution Sexuelle» O. Adriano Olivy OP, „Studia Theologica Varsaviensia” 2016, nr 1, s. 223-247, URL:

https://czasopisma.uksw.edu.pl/index.php/stv/article/view/1899/1734, https://doi.org/10.21697/stv.2016.54.1.11.

Clague J., Gender and Moral Theology: A Shared Project, w: Catholic Theological Ethics: Past Present, and Future, ed. J.F. Keenan, Orbis Books, Maryknoll, New York 2011, s. 282-295.

Cornish P.J., Marriage, Slavery, and Natural Rights in the Political Thought of Aquinas, „The Review of Politics” 1998, Vol. 60, No. 3, s. 545-561, https://doi.org/10.1017/S0034670500027467.

Eco U., In Praise of Thomas Aquinas, „The Wilson Quarterly” 1986, Vol. 10, No. 4, s. 78-87.

Farley M.A., Just Love: A Framework for Christian Sexual Ethics, Continuum, New York 2006.

Ferrante J.M., The education of women in the Middle Ages in theory, fact, and fantasy, w: Beyond Their Sex: Learned Women of the European Past, ed. P.H. Labalme, New York University Press, New York 1980, s. 9-42.

Finley J., The Metaphysics of Gender: A Thomistic Approach, „The Thomist: A Speculative Quarterly Review” 2015, Vol. 79, No. 4, s. 585-614,

https://doi.org/10.1353/tho.2015.0031.

Firer Hinze C., Women, Families, and the Legacy of Laborem Exercens: A finished Agenda, „Journal of Catholic Social Thought” 2009, Vol. 6, No. 1, s. 63-92, 
URL: http://www.virtualplater.org.uk/wp-content/uploads/2011/10/Firer-Hinze-in-J-of-CSTh-2009.pdf.

Fullam L., Toward a Virtue Ethics of Marriage: Augustine and Aquinas on Friendship in Marriage, „Theological Studies” 2012, Vol. 73, No. 3, s. 663-692, https:// doi.org/10.1177/004056391207300309.

Gaillardetz R.R., The Groupe des Dombes Document "One Teacher" (2005): Toward a Postconciliar Catholic Reception, „Theological Studies” 2013, Vol. 74, No. 1, s. 20-47, https://doi.org/10.1177/004056391307400102.

Grimes K., Butler Interprets Aquinas. How to Speak Thomistically About Sex, „The Journal of Religious Ethics” 2014, Vol. 42, No. 2, s. 187-215, https://doi. org/10.1111/jore.12053.

Hall P., Narrative and the Natural Law: An Interpretation of Thomistic Ethics, Notre Dame, Indiana, 1994.

Hartel J., The Integral Feminism of St. Thomas Aquinas, „Gregorianum” 1996, Vol. 77, No. 3, s. 527-547, URL: http://www.laityfamilylife.va/content/dam/ laityfamilylife/Documenti/donna/filosofia/english/integral-feminism-of-st-thomas-aquinas.pdf.

Keenan J.F., A History of Catholic Moral Theology in the Twentieth Century: From Confessing Sins to Liberating Consciences, Continuum, London 2010.

Lichacz P., O łączeniu myśli feministycznej z tomistyczną, „Studia Antyczne i Mediewistyczne" 2014, nr 12(47), s. 139-151.

McCluskey C., An Unequal Relationship Between Equals: Thomas Aquinas On Marriage, „History of Philosophy Quarterly” 2007, Vol. 24, No. 1, s. 1-18.

Miller J., A Note On Aquinas: And Ordination Of Women, „New Blackfriars” 1980, Vol. 61, No. 719, s. 185-190, https://doi.org/10.1111/j.1741-2005.1980. tb06920.x.

Firer Hinze C., Hornbeck II J.P., ed., More than a Monologue: Sexual Diversity and the Catholic Church, Vol. 1, Voices of Our Times, Fordham University Press, New York 2014.

Firer Hinze C., Hornbeck II J.P., ed., More than a Monologue: Sexual Diversity and the Catholic Church, Vol. 2, Inquiry, Thought and Expression, Fordham University Press, New York 2014.

Murphy W.F., Revisiting Contraception: An Integrated Approach in Light of the Renewal of Thomistic Virtue Ethics, „Theological Studies” 2011, Vol. 72, No. 4, s. 812-847, https://doi.org/10.1177/004056391107200406. 
Nolan M., Aquinas and the Act of Love, „New Blackfriars” 1996, Vol. 77, No. 902, s. 115-130, https://doi.org/10.1111/j.1741-2005.1996.tb01537.x.

Nolan M., The Aristotelian Background to Aquinas's Denial that "Woman is a Defective Male», "The Thomist” 2000, Vol. 64, No. 1, s. 21-69, https://doi.org/10.1353/tho.2000.0001.

Nussbaum M., Social Justice and Universalism: In Defense of an Aristotelian Account of Human Functioning, „Modern Philology” 1993, nr 90, s. 46-73.

Oliva A., Amours. L'Église, les divorcés remariés, les couples homosexuels, Les Éditions du Cerf, Paris 2015.

Oliva A., Essence et finalité du mariage selon Thomas d'Aquin: pour un soin pastoral renouvelé, „Revue des Sciences philosophiques et théologiques” 2014, Vol. 98, No. 4, s. 601-668, https://doi.org/10.3917/rspt.984.0601.

Penczek M., Wola i intelekt w filozofii Tomasza z Akwinu, Wydawnictwo Uniwersytetu Jagiellońskiego, Kraków 2012.

Serrano del Pozo I., Algo imperfecto y ocasional. Una relectura a la controvertida tesis de Tomás de Aquino sobre la mujer, „Divus Thomas” 2018, Vol. 121, No. 3, s. 268-280.

Sommer V., ed., Homosexual Behaviour in Animals. An Evolutionary Perspective, Cambridge University Press, Cambridge 2006.

Sowle Cahill L., Catholic Feminists and Traditions: Renewal, Reinvention, Replace, „Journal of the Society of Christian Ethics” 2014, Vol. 34, No. 2, s. 27-51, https://doi.org/10.1353/sce.2014.0029.

Staples K.K., Medieval Europe, w: A Companion to Global Gender History, ed. T.A. Meade, M.E. Wiesner-Hanks, Wiley-Blackwell, Hoboken 2021.

Środa M., Czy etyka ma płeć?, „Etyka” 2012, nr 45, s. 7-15, URL: https://etyka. uw.edu.pl/index.php/etyka/article/view/877/829, https://doi.org/10.14394/ etyka.877.

Traina C.L.H., Feminist Ethics and Natural Law: The End of the Anathemas, Georgetown University Press, Washington, DC 1999.

Trepczyński M., Ishikawa T., Czy kobieta to niewydarzony mężczyzna? Metafizyka płci z perspektywy Tomasza z Akwinu i dzisiejszej biologii, „Przegląd Filozoficzny - Nowa Seria” 2017, nr 2(102), s. 237-254, URL: https://journals. pan.pl/dlibra/publication/115641/edition/100511/content.

Uliński M., Płeć jako determinanta roli i pozycji społecznej według nauki Arystotelesa, „Archiwum Historii Filozofii i Myśli Społecznej” 1996, nr 41, s. 3-20. 
Vega-Frutis R., Macias-Ordoñez R., Guevara R., Fromhage L., Sex change in plants and animals: a unified perspective, "Journal of Evolutionary Biology” 2014, 27, s. 667-675, https://doi.org/10.1111/jeb.12333.

\section{Streszczenie}

W kontekście studiów kobiecych Tomasz z Akwinu jest prawdopodobnie najbardziej znany z głoszenia parafrazy poglądu Arystotelesa, który nazywa kobietę „niedorozwiniętym mężczyzną”. O ile Stagiryta rzeczywiście przyjmuje wątpliwą empirycznie przesłankę o inherentnej kobiecie niższej wartości wobec mężczyzny, którą konsekwentnie realizuje na stronach swoich wielu dzieł, o tyle w przypadku Tomasza problematyka płciowości nie jest podjęta w sposób tak oczywisty i ostateczny. Akwinata przede wszystkim nie nazywa kobiety „czymś niedorozwiniętym”, a „jedynie” okazjonalnym. Ma to odniesienie do jego teorii ontologicznej, w ramach której kobieta jest bytem okazjonalnym na poziomie jednostkowym, lecz koniecznym na poziomie ogólnym. Chociaż przyjmuje pewne twierdzenia Arystotelesa (takie jak upośledzoną racjonalność kobiety i jej naturalne poddaństwo wobec mężczyzny), to odrzuca inne, ukazujące ją jako istotę pozbawioną godności. Jeśli przyjmie się wyższość sfery duchowej nad cielesną, to ostatecznie odczytanie myśli Akwinaty na sposób quasi-feministyczny jest możliwe, czego dowodem jest np. istnienie katolickiego feminizmu neotomistycznego. Do jego osiągnięć zalicza się m.in. uznawanie rozwodów małżeństw, w których nie ma przyjaźni, porzucenie Arystotelowskiej biologii na rzecz współczesnej wiedzy naukowej oraz wskazanie na możliwość feministycznej interpretacji koncepcji prawa naturalnego, które powinno obejmować dobrostan kobiet i mniejszości.

Słowa kluczowe: Tomasz z Akwinu, Arystoteles, płeć, kobiecość, ontologia płci, feminizm neotomistyczny 


\section{Summary}

\section{Woman and Femininity in Thomas Aquinas and Neo-Thomistic Feminist Ethics. A Critical Analysis}

Within the context of women's studies, Thomas Aquinas is probably best known for his paraphrase of Aristotle's view, which describes woman as a "deformed man". While the Philosopher indeed adopts the empirically dubious premise of woman's value being intrinsically inferior to man, which he consistently implements throughout the pages of his many works, in Thomas's case the issue of gender is not addressed so clearly and definitively. Above all, Aquinas does not call woman "something deformed", but "only" occasional and misbegotten. This is a reference to his ontological theory, in which woman is an occasional entity on the individual level, but a necessary one on the general level. He also distinguishes two relations of equality and affirms one of them to exist between woman and man. Although he accepts some of Aristotle's beliefs (such as the impaired rationality of woman and her natural submission to man), he rejects others which show her as a being devoid of dignity. If one accepts the superiority of the spiritual sphere over the bodily one, it is ultimately possible to interpret Aquinas's thought in a quasi-feminist way, as evidenced by the existence of Catholic NeoThomistic feminism, among others. Its achievements include recognising the divorce of marriages in which there is no friendship, abandoning Aristotelian biology in favour of modern scientific knowledge, and indicating the possibility of a feminist interpretation of the concept of natural law, which should include the welfare of women and minorities.

Key words: Thomas Aquinas, Aristotle, gender, femininity, ontology of gender, Neo-Thomistic feminism 